\section{Zero-sum game}

Burton Richter, the director of the Stanford Linear Accelerator Center (SLAC), has proposed halving his own budget to pay for a new accelerator that federal officials decided two months ago was too expensive to fund until later in the decade. But Richter, who believes that the new machine is essential to keep his laboratory at the forefront of research in the field, must first convince his colleagues in the high-energy physics community that the money is his to spend and that a $\mathbf{\$ 1 5 0}$-million machine is the best way to use scarce federal funds.

Rather than wait for the US Department of Energy (DOE) to provide the money for a new collider to create subatomic B mesons, Richter hopes to take matters into his own hands. At a presentation last month to a priority-setting subcommittee of DOE's High Energy Physics Advisory Panel (HEPAP), Richter proposed to suspend the current SLAC experimental programme for six months of the year and use the $\$ 70$ million saved to build the new accelerator.

But Richter's view of the SLAC budget irritates many other physicists in the community. "He says it's his money - I say it's the biggest scandal in high-energy physics", says Thomas Kirk, head of the high energy physics division at the Argonne National Laboratory. "It's not God-given that every lab gets a certain budget", adds Charles Baltay, a Yale University physicist and a member of the team now running an experiment at SLAC.

In January, DOE and the National Science Foundation (NSF), the two agencies that have solicited proposals for what is being called a $B$ factory, decided that the prospects for high-energy physics funding were too "bleak" to permit consideration of a $\mathbf{B}$ factory until late in the decade. Besides dashing SLAC's hopes, the decision put a halt to efforts to build a similar large machine at Cornell University, which has an NSF-funded accelerator facility. Cornell also plans to divert small amounts of its budget over several years to accomplish, in a less theatrical manner than Richter, the same end.

But SLAC, which has suffered an ignominious loss to the European Large Electron Positron detector in the race to create $\mathrm{Z}$ particles (see page 99 ), is facing more than just the loss of a new accelerator. With little prospect of doing new physics at the facility, many physicists are wondering whether even half its current budget is too much.

That question is in the hands of a subpanel of HEPAP, which met this week to examine priorities for the field. The subpanel will make its recommendations to the full advisory committee on 13 April. Christopher Anderson

\title{
Tough times ahead
}

\section{New Delhi}

GOVERNMENT scientists in India will have less money to spend this year as a result of across-the-board cuts in the budget announced last week.

The 1992-93 budget, presented to Parliament in the midst of an economic crisis, provides for an increase for research and development that fails to keep pace with the country's 12 per cent annual rate of inflation. The new budget contains $\$ 872$ million for science, which represents about $\$ 40$ million less in purchasing power than the current budget. Those figures do not include $\$ 390$ million for defence research.

The budget squeeze has forced scientific agencies to re-define their priorities. The space department, which will receive $\$ 190$ million, has decided to spend $\$ 25$ million less this year on the development of satellites and on applied research. The atomic energy department now plans to build two nuclear power plants rather than six.

The Scientific Workers Association, representing the 8,000 employees in the 42 laboratories of the Council of Scientific and Industrial Research, has warned management that it will not tolerate any layoffs or laboratory closures as a way of helping to ease the budget deficit. Never- theless, the deficit has already forced some scientists to look for new jobs. Last month, the government decided to close down the 34-year-old National Buildings Organization, which designs low-cost housing, sets building standards and conducts research on alternative materials. Some 110 scientists and engineers are losing their jobs, and have been encouraged to find work with nongovernment bodies.

The cuts, combined with a devaluation last October of the rupee, have also devastated laboratories that rely on materials from abroad. Many institutes have halved their subscriptions to foreign journals and their book purchases, as well as trimming their purchases of equipment and instrumentation.

There were signs of hard times for Indian science even before last week's announcement. In December, all departments were asked to abolish 10 per cent of their middle- and upper-level administrative posts; more than half of those posts are held by scientists and technology experts. The government has also refused to name a new head for the Department of Ocean Development in what may be a prelude to abolishing the department.

K.S. Jayaraman

\section{Pressure grows on Panjab University}

\section{New Delhi}

INDIA's scientific community seems at last alerted to the implications of last month's surprise reinstatement of palaeontologist V.J. Gupta as a senior professor of the Panjab University. Meanwhile, at Chandigarh, the continuing investigation of Gupta's alleged misuse of fossil evidence has taken a bizarre turn: the few among Gupta's local colleagues who helped frame charges against him have been asked to explain why they are not equally at fault.

Three of Gupta's former colleagues are especially fearful of victimisation. Summoned to appear on 29 February before M.J. Gujral, a retired high-court judge who was appointed by the university to complete the investigation of the allegations against Gupta, they declined to appear. Arun Ahluwalia, one coworkerturned critic, says it is ironic that "those who have spoken the truth should have been put on the defensive" while Gupta is "firmly back in his chair".

The university explains that it reinstated Gupta before completing its investigation because it "can neither keep a confirmed employee on suspension indefinitely, nor act on allegations without observing the due process of law".

Those summoned before the Gujral inquiry are drawn only from among Gupta's coworkers at the Panjab University, 14 of whom have stayed out of the controversy of the past three years. Ahluwalia believes that he and his fellowcritics are being held hostage for Gupta's reinstatement as head of department next month, and that the investigation will be biased by Gupta's 1,000-page defence of himself.

But the university's sleight-of-hand has excited scepticism elsewhere in India. A.S. Paintal was director of the all-India Institute of Medical Research whose expedition to the Himalayas last summer failed to confirm Gupta's claims. Speaking this week as president of the Society for Scientific Values, he said that "we will not tolerate a cover-up". If the university tried a "whitewash", he would go "right to the Prime Minister".

The University Grants Committee (UGC), the chief source of university funds, is also exercised. Its chairman, G. Rami Reddy, promises to make public the report drawn up by the expedition of the Geological Society of India, financed by UGC and three other agencies, "as soon as I can lay hands on it". Reddy says that UGC will cut off Chandigarh's funds if necessary.

K.S. Jayaraman 